\title{
Effect of different doses and application methods of sodium selenate on selenium status in maize for silage
}

\author{
Emir Džomba ${ }^{1}$, Mirha Đikić ${ }^{2}$ Drena Gadžo ${ }^{2}$, Senada Čengić-Džomba ${ }^{1}$, Zdenko Lončarić ${ }^{3}$ and Bal Ram Singh ${ }^{4}$ \\ ${ }^{1}$ Department of Animal Production; Faculty of Agriculture and Food Sciences, University of Sarajevo, 71000 Sarajevo, \\ Bosnia and Herzegovina \\ ${ }^{2}$ Field Crop Production Department, Faculty of Agriculture and Food Sciences, University of Sarajevo, 71000 Sarajevo, \\ Bosnia and Herzegovina \\ ${ }^{3}$ Institute for Agroecology, Faculty of Agriculture, University Josip Juraj Strossmayer, 31000 Osijek, Croatia \\ ${ }^{4}$ Department of Plant and Environmental Sciences (IPM), Norwegian University of Life Sciences, \\ P.O. Box 5003 NO-1432 Ås, Norway \\ e-mail:e.dzomba@ppf.unsa.ba
}

\begin{abstract}
A two-year field study was conducted to determine the effect of different Se fertiliser application methods and application rates on the selenium content in maize plants. Selenium as sodium selenate was added into soil ( $10 \mathrm{~g}$ and $20 \mathrm{~g} \mathrm{Se} \mathrm{ha}^{-1}$ ) or sprayed on maize plants $\left(20 \mathrm{~g} \mathrm{Se} \mathrm{ha}^{-1}\right)$. Maize plants from control treatment contained 0.018 and $0.020 \mathrm{mg} \mathrm{Se} \mathrm{kg} \mathrm{DM}^{-1}$ in the first and the second year of the study. Foliar application exhibited superior effect by increasing selenium content in the plants up to $0.343 \mathrm{mg} \mathrm{kg} \mathrm{DM}^{-1}$ in the first year, and $0.249 \mathrm{mg} \mathrm{kg} \mathrm{DM}^{-1}$ in the second. Soil selenium application was less effective; selenium content in maize plants varied from 0.018 to $0.019 \mathrm{mg}$ $\mathrm{kg} \mathrm{DM}^{-1}$ in the first and from 0.018 to $0.145 \mathrm{mg} \mathrm{kg} \mathrm{DM}^{-1}$ in the second year, respectively. Strong linear correlation $(r=0.71)$ was found between selenium content in the plants and in grains. Selenium recovery rates were significantly higher in case of foliar treatment compared to soil application.
\end{abstract}

Key words: selenium, foliar, soil, application, hybrids

\section{Introduction}

Numerous surveys worldwide have shown selenium shortage in ruminant nutrition. Selenium has essential role in mammalian bodies, taking part in synthesis of various proteins including glutathione peroxidase, selenoprotein $\mathrm{P}$, selenoproteins $\mathrm{W}$ and $\mathrm{R}$, type I iodothyronine 5'-deiodinase and thioredoxin reductase (Tapiero et al. 2003). Selenium deficiency in nutrition of ruminants causes numerous disorders, including nutritional muscular disease, reduced growth rate, retained placenta, impaired fertility and mastitis (Pehrson 1993).

Many different methods have been used to increase selenium status in ruminants. Inorganic selenium added directly to soil or as foliar fertilizer can improve selenium status in plants and consequently in animals. These two methods of supplementation were commonly used and intensively studied in Finland (Gissel-Nielsen 1993, Yläranta 1993) and New Zealand (Witchel 1998), where selenium in the form of selenite and selenate was added to fertilizers, sprayed on plants, or seeds were treated with aqueous solutions of selenium compounds. Proponents of this type of selenium supplementation highlighted the facts that a very small amount of selenium was sufficient to raise its content in plants to a desired level. Additionally, selenium in plants is in organic form (selenium-amino acids), what is safer than adding inorganic selenium directly to the animal feed. On the other hand, a study conducted in Finland (Yli-Halla 2005), which reviewed efficacy of applying selenium fertilizers in soil over a period of 13 years, found that only $8 \%(0.7-22 \%)$ of selenium added to the soil was actually taken up by plants. Selenium recovery in plant tissues was more effective after foliar application (Aspila 2005, Seppänen et al. 2010) due to avoidance of root to shoot translocation of Se (Winkel et al. 2015); however it varied depending on plant development phase and weather conditions during and after selenium application. Generally, the effectiveness of increasing selenium content in plants depends on the form of selenium fertilizers, fertilizing dose, application technique and soil properties, selenium concentration and form in the soil, plant genotype, climatic conditions and plant maturity at harvesting (Surai et al. 2008, Ros et al. 2016). Agricultural practices such as fertilization with phosphorus, nitrogen or sulfur, irrigation, liming, etc. also influence selenium bioavailability in the soil and its uptake by plants. However, fertilization of crops using inorganic selenium sources remains the most common practice when wanting to increase selenium content in plants (Lyons et al. 2003, Broadley et al. 2006, Ros et al. 2016). 
Sodium selanate and sodium selenite are two forms of selenium that are most commonly used in plant biofortification. Selenate is more water soluble and consequently more bioavailable then selenite (Missana et al. 2009). Additionally, mechanisms of selenium uptake in plants are different: selenite is transported by phosphate transport mechanism (Li et al. 2008) while selenate is taken up by plants through sulfate transporters and channels (Terry et al. 2000). Selenium is transported through plants via the xylem and accumulated in various part of plants depending of genotype. Selenium concentrations in upper parts of plants (e.g. leaves, grains, fruits) were higher than in the stem (Sakizadeh et al. 2016), indicating seasonal fluctuation of selenium content in plants (Galeas et al. 2007). Typically, selenium concentration in younger leaves of plants is higher than in the older ones or in the seeds (Cappa et al. 2014). Ebrahimi at al. (2015) noticed translocation of selenium accumulated in leaves during vegetative phase of plant development into siliques at reproductive stage of oilseed rape.

Since selenium is not essential for plants, low genetic variability could be expected in terms of accumulation of selenium in plant tissues. According to Stadlober et al. (2001), among the common cereal crops, wheat is the most efficient accumulator of selenium. It seems that there are noticeable variation among genotypes of a particular species in terms of its ability to accumulate selenium. A study conducted by Lyons et al. (2005) showed no significant genetic variation of selenium content in grain among modern varieties of wheat, triticale and barley. On the other hand, Mangan et al. (2016) found remarkable variation of selenium content in grains of different maize and barley varieties. Reviewing selenium accumulation by plants, White (2016) noted findings of many authors regarding variation in selenium concentrations among different genotypes of wheat, barley, oat, rice, common bean, broccoli, onion, etc. grown under the same conditions.

Many different criteria are being used to establish selenium requirement and there is no agreement in scientific literature of what would be adequate selenium supply in animals. According to NRC (2001) nutritional requirement of selenium, dairy cows need $0.3 \mathrm{mg} \mathrm{kg}^{-1}$ of dry matter (DM). Suttle (2010) declares selenium concentrations between 0.02 and $0.08 \mathrm{mg} \mathrm{kg}^{-1} \mathrm{DM}$ as marginal limits of selenium deprivation in cattle fed diets with adequate content of vitamin E. Under conditions of oxidative stress or when animals kept indoors, the given values could be doubled. Taking into account relatively low coefficient of selenium absorption (40\%) total dietary selenium requirements would be more than $4 \mathrm{mg}^{\text {day }}{ }^{-1}$ (NRC 2001).

Selenium content in maize silage significantly affects selenium status in ruminants. Maize silage is one of the most commonly used forages for ruminants in temperate regions. New maize hybrids are better adapted to cold climates allowing their production for silage on larger areas worldwide. Additionally, CLIMEX distribution model predicted that many regions, including Nordic countries, would shift from marginally to mediumly suitable areas for maize production (Ramirez-Cabral et al. 2017). Selenium deficiencies in cattle and sheep have been confirmed under natural grazing conditions in many regions/countries of the South Eastern Europe (Antunović et al. 2010, Džomba et al. 2014, Ademi et al. 2015) and in particular in the Scandinavian countries (Yläranta 1993, Seppälä et al. 2014). Recent investigation conducted in Southeastern Europe (Serbia) suggested that maize silage contained less than $0.2 \mathrm{mg} \mathrm{Se} \mathrm{kg}^{-1} \mathrm{DM}$ (Marijanušić et al. 2017), what could be below recommended values for dairy cows. Additionally, a significant amount of selenium could be lost during ensiling, particularly if plants contained low amounts of dry matter (Seppälä et al. 2014). The gap between recommended amount and actual intake of selenium could be bridged by use of commercially manufactured selenium fortified animal feed what is common practice in nonruminant nutrition. Various supplementation strategies (injectable selenium, addition of organic selenium sources in the diet, etc.) have been used to compensate for selenium shortage in ruminant nutrition, but such solutions are more expensive than biofortification of fodder with selenium. Worldwide, numerous studies have been conducted on use of soil or foliar selenium biofortification with the aim increasing selenium content in vegetables, fodder, crop, etc. but data on selenium biofortification of maize plant used for silage is scarce in scientific literature. The aim of this paper is to determine the effect of sodium selenate applied directly into soil and in the form of foliar spray on increasing selenium content in maize plants to the level of $0.1 \mathrm{mg} \mathrm{kg}^{-1} \mathrm{DM}$, as that level is considered might be sufficient for ensuring satisfactory selenium supply of cattle feeding by completely mixed diets (forages plus concentrates).

\section{Materials and methods}

\section{Experimental location}

The experiment was conducted during two consecutive years under common farming practice conditions in Butmir, Sarajevo ( $43^{\circ} 82^{\prime} \mathrm{N} 18^{\circ} 32^{\prime} \mathrm{E}$, elevation $484 \mathrm{~m}$ ) in Bosnia and Herzegovina. The climatic conditions during two years of the study varied considerably. The annual precipitation was $1083 \mathrm{~mm}$ in 2014 and $766 \mathrm{~mm}$ in 2015. 
About $55 \%$ of total rainfall in the first and $35 \%$ in the second year were received between July and September. At the same time, the mean annual temperatures were $11.6^{\circ} \mathrm{C}$ and $10.1{ }^{\circ} \mathrm{C}$ with vegetative season average of 17.0 ${ }^{\circ} \mathrm{C}$ and $19.3{ }^{\circ} \mathrm{C}$ for 2014 and 2015, respectively. The soils were classified as Eutric Cambisol. The main characteristics of the experimental soils are given in Table 1.

Table 1. Chemical characteristics of the soils

\begin{tabular}{ccccccc}
\hline & $\mathrm{pH}^{*}$ & Humus, $\%$ & $\mathrm{~N}, \%$ & $\mathrm{P}, \mathrm{mg} \mathrm{kg} \mathrm{mg} \mathrm{kg}^{-1}$ & $\mathrm{Se}, \mathrm{mg} \mathrm{kg}^{-1}$ \\
\hline 2014 & 6.45 & 3.02 & 0.15 & 76.9 & 139.3 & 0.19 \\
2015 & 6.56 & 4.30 & 0.21 & 92.0 & 315.6 & 0.24 \\
\hline
\end{tabular}

*Measured in water

The soils were slightly acidic with adequate supply of organic matter and contained sufficient amount of phosphorus and potassium (Egnèr et al. 1960). In terms of selenium content, the investigated soils were classified as selenium deficient because selenium content in soil below $0.5 \mathrm{mg} \mathrm{kg}^{-1}$ is not likely ensure enough selenium in crops or pasture to meet nutritional requirements of cows (Underwood and Suttle 1999).

\section{Experimental design and procedure}

The experiment used the split plot factorial design based on a completely randomized block system with four replications. Main plots were two hybrids of maize and subplots were subjected to selenium fertilization in the form of sodium selenate at level of $0 \mathrm{~g} \mathrm{ha}^{-1}(\mathrm{SeC}), 10 \mathrm{~g} \mathrm{ha}^{-1}$ (Se10) and $20 \mathrm{~g} \mathrm{ha}^{-1}$ (Se20) applied into soil before sowing, with addition of foliar application of $20 \mathrm{~g} \mathrm{Se} \mathrm{ha}^{-1}$ (Se2OF) at the phase of intensive growth of plants. Soil selenium applied as sodium selenate solution was sprayed on the soil surface by manual sprayer and then incorporated by harrow into upper 10-15 cm of soil. Maize hybrids were PR36R10 (R10) FAO group 400 and PR37N01 (N01) FAO group 410. The subplot size was $4 \times 5 \mathrm{~m}$. Maize seeds were planted $20 \mathrm{~cm}$ apart with $70 \mathrm{~cm}$ between rows, achieving densities of 62500 plants ha ${ }^{-1}$. The seeds were sown on 21 April 2014 and 26 April 2015, manually, at the depth of $4 \mathrm{~cm}$. All plots were fertilized before sowing using $100 \mathrm{~kg} \mathrm{~N} \mathrm{ha}^{-1}$ in the form of urea and $35 \mathrm{~kg} \mathrm{P} \mathrm{ha}^{-1}$ in the form of triple superphosphate. Additionally, $100 \mathrm{~kg} \mathrm{~N} \mathrm{ha}^{-1}$ in the form of urea were applied in the phase of intensive growth of plants. The weeds were controlled by use of registered herbicides.

\section{Sampling and analysis}

Topsoil $(0-30 \mathrm{~cm})$ sampling was done before the seeds were sown. The final harvest was performed simultaneously at all blocks in mid-September (approximately when the kernel milk line was between one-half and twothirds). Before the harvest, the number and height of plants at each plot was determined. Five plants from each plot were harvested, weighted and chopped to the size suitable for ensiling. The subsample of plants from each plot was used for chemical analysis. In the second year of the research, samples of maize grains were also taken.

Soil potassium and phosphorus were determined according to ammonium lactate-acetic acid extraction procedure described by Egnèr et al. (1960), and after that, the extracted phosphorus was measured colorimetrically, while potassium was measured by flame photometry. Soil pH was determined in a 1:5 (v/v) suspension of soil in water (ISO 1994) and content of organic matter in the soil was determined by wet combustion of soil samples in $\mathrm{H}_{2} \mathrm{SO}_{4}$ and $\mathrm{K}_{2} \mathrm{Cr}_{2} \mathrm{O}_{7}$ - dichromate method (Mineev et al. 2001). Soil organic matter was digested by aqua regia (ISO 1995), and selenium concentrations were determined using a Perkin Elmer Optima 5300 DV Inductively Coupled Plasma Optic Emission Spectrometer (ICP-OES). The plant samples were analyzed after microwave digestion using $9 \mathrm{ml} 65 \%(\mathrm{v} / \mathrm{v}) \mathrm{HNO}_{3}$ and $2 \mathrm{ml} \mathrm{30 \%} \mathrm{(v/v)} \mathrm{H}_{2} \mathrm{O}_{2}$ (Kingstone and Jassie 1986). The selenium concentrations were determined by inductively coupled plasma IICP), optical emission spectrometry (OES) technique.

\section{Data processing}

Dry matter yield (DMY) was estimated on the basis of weighted values of plants, total number of plants and dry matter content in plants from each plot. Total selenium accumulation (TASe, $\mathrm{mg} \mathrm{ha}^{-1}$ ) in plants was determined as the product of selenium concentration in plants and the plant biomass yield (all expressed on dry matter basis). The recovery efficiency of applied selenium (RESe, \%) was estimated as a ratio of difference between TASef and TASec and applied Se at Sef (adapted from Wang et al. 2013) 


$$
\text { RESe, } \%=\frac{\text { TASe }_{f}-\mathrm{TASe}_{c}}{\mathrm{Se}_{\mathrm{f}}} \times 100
$$

where $\mathrm{f}$ and $\mathrm{c}$ denote selenium fertilizers and control treatment, respectively.

Statistical analysis of selenium fertilizers effect on selenium content in maize plants was performed by variance analysis (General Linear Model) in SPSS 17 (SPSS Inc., Chicago, IL, USA). Hybrids and effects of the selenate as well as their interactions were compared using LSD test.

\section{Results}

The selenium fertilizers were found to have significant effect on selenium content in plants, selenium accumulation and selenium recovery in both years of the trial, and also on selenium content in grains in the second year at probability level $p<0.001$. Taking into consideration the experimental years, maize hybrids' responses to the applied treatments differed, showing more pronounced effect in the second year. However, influence of genotype on the selenium uptake and accumulation was not as apparent as the influence of fertilizers. Neither selenium fertilizers nor maize genotype showed significant effects on biomass yield in either year (Tables 2 and 3 ).

Table 2. Analysis variance (showing mean squares) for the effects of the experimental treatments on the selenium content and dry matter yield (DMY) of the maize in 2014

\begin{tabular}{|c|c|c|c|c|c|c|}
\hline \multirow[t]{2}{*}{ SOV$^{a}$} & \multirow[t]{2}{*}{$d f$} & \multicolumn{3}{|c|}{ Mean squares } & \multirow[t]{2}{*}{$d f$} & \multirow{2}{*}{$\frac{\text { Mean squares }}{\text { RESe }}$} \\
\hline & & DMY & Se in plants & TASe & & \\
\hline Selenium (Se) & 3 & $3.982^{\text {ns }}$ & $0.211 * * *$ & $57055764 * * *$ & 2 & $1898.82^{* * *}$ \\
\hline Error Se & 9 & 2.475 & 0.03 & 488054 & 6 & 16.59 \\
\hline Hybrid (H) & 1 & $14.472^{\text {ns }}$ & $0.003^{*}$ & $298260^{\text {ns }}$ & 1 & $18.44^{\text {ns }}$ \\
\hline Error $\mathrm{H}$ & 3 & 2.377 & 0.000 & 17279736 & 3 & 5.26 \\
\hline $\mathrm{Se} \times \mathrm{H}$ & 3 & $3.805^{\text {ns }}$ & $0.003^{\mathrm{ns}}$ & $460333^{\text {ns }}$ & 2 & $14.71^{\text {ns }}$ \\
\hline Error $\mathrm{Se} \times \mathrm{H}$ & 9 & 2.466 & 0.001 & 236254 & 6 & 8.46 \\
\hline
\end{tabular}

*,*** Significant at the $5 \%$ and $0.1 \%$ level of probability; ${ }^{\text {ns }}=$ not significant; ${ }^{a}=$ Sources of variation

Table 3. Analysis variance (showing mean squares) for the effects of the experimental treatments on the selenium content and biomass yield of the maize in 2015

\begin{tabular}{|c|c|c|c|c|c|c|c|}
\hline $\mathrm{SOV}^{\mathrm{a}}$ & df & & & Mean squares & & df & Mean squares \\
\hline & & DMY & Se in plants & Se in grains & TASe & & RESe \\
\hline Selenium (Se) & 3 & $0.291^{\mathrm{ns}}$ & $0.091 * * *$ & $0.066 * * *$ & $1709038394 * * *$ & 2 & $280.90 * * *$ \\
\hline Error Se & 9 & 0.232 & 0.000 & 0.002 & 19775972 & 6 & 3.51 \\
\hline Hybrid $(\mathrm{H})$ & 1 & $2.814^{\mathrm{ns}}$ & $0.009 * *$ & $0.002^{\text {ns }}$ & $148687633^{*}$ & 1 & $68.81^{*}$ \\
\hline Error $\mathrm{H}$ & 3 & 5.136 & 0.000 & 0.005 & 13762644 & 3 & 5.54 \\
\hline $\mathrm{Se} \times \mathrm{H}$ & 3 & $1.426^{\mathrm{ns}}$ & $0.001^{\text {ns }}$ & $0.001^{\text {ns }}$ & $282020^{\text {ns }}$ & 2 & $0.896^{\mathrm{ns}}$ \\
\hline Error $\mathrm{Se} \times \mathrm{H}$ & 9 & 1.199 & 0.001 & 0.004 & 22374370 & 6 & 8.02 \\
\hline
\end{tabular}

$*, * *, * * *$ Significant at the $5 \%, 1 \%$ and $0.1 \%$ level of probability; ${ }^{\text {ns }}=$ not significant; ${ }^{\text {a }}=$ Sources of variation

The average dry matter biomass yield with soil selenium application varied between 15.79 and $17.92 \mathrm{t} \mathrm{ha-1}$ in 2014, and between 12.87 and $13.96 \mathrm{t} \mathrm{ha}^{-1}$ in 2015. The higher biomass yield in the first year was a consequence of more favorable climatic factors (the amount of rainfall and its distribution during the vegetative season) resulting in higher and denser distributions of plants. Selenium concentration in plants in control treatments was similar in both years indicating insufficient selenium content in ruminant nutrition. Selenium fertilizers have significantly increased selenium content in plants with the most pronounced effect being observed in case of foliar fertilization with selenium (Tables 4 and 5). Selenate application in soil in both doses was relatively ineffective in terms of raising selenium concentrations in the entire maize plants and grains to the target selenium concentrations. Only Se20 treatment in the second year resulted in plants selenium concentrations raising above threshold. 
Table 4. Mean comparison of selenium concentrations in maize and biomass yield affected by the main effects of the experimental treatments in 2014

\begin{tabular}{|c|c|c|c|c|}
\hline Treatment & DMY, t ha ${ }^{-1}$ & Se in plants, $\mathrm{mg} \mathrm{kg}^{-1} \mathrm{DM}$ & TASe, mg ha-1 & RESe, \% \\
\hline \multicolumn{5}{|l|}{ Selenium } \\
\hline $\mathrm{SeC}$ & 16.72 & $0.0176^{c}$ & $296.09^{b}$ & \\
\hline Se10 & 15.79 & $0.0184^{\mathrm{bc}}$ & $290.52^{\mathrm{b}}$ & $-0.06^{b}$ \\
\hline Se20 & 17.92 & $0.0192^{b}$ & $344.16^{b}$ & $0.24^{b}$ \\
\hline Se2OF & 16.46 & $0.3435^{a}$ & $5651.19^{a}$ & $26.78^{a}$ \\
\hline Hybrid $^{H}$ & ns & $*$ & ns & ns \\
\hline N01 & 17.02 & 0.091 & 1548.95 & 8.11 \\
\hline R10 & 15.98 & 0.109 & 1742.03 & 9.86 \\
\hline
\end{tabular}

$\mathrm{a}, \mathrm{b}, \mathrm{c}$, Values denoted by same letter within each column are not statistically significant; ${ }^{\mathrm{H}}$ Denotes statistical differences between N01 and R10 hybrids; ns = not significant; ${ }^{*}=$ significant at $5 \%$ level of probability

Table 5. Mean comparison of selenium concentrations in maize and biomass yield affected by the main effects of the experimental treatments in 2015

\begin{tabular}{|c|c|c|c|c|c|}
\hline Treatment & DMY, t ha-1 & Se in plants, $\mathrm{mg} \mathrm{kg}^{-1} \mathrm{DM}$ & Se in grains, $\mathrm{mg} \mathrm{kg}^{-1} \mathrm{DM}$ & TASe, $\mathrm{mg} \mathrm{ha}^{-1}$ & RESe, \% \\
\hline \multicolumn{6}{|l|}{ Selenium } \\
\hline $\mathrm{SeC}$ & 13.96 & $0.0111^{d}$ & $0.0196^{d}$ & $154.95^{d}$ & \\
\hline Se10 & 12.87 & $0.0184^{c}$ & $0.0627^{c}$ & $236.61^{c}$ & $0.81^{c}$ \\
\hline Se20 & 13.51 & $0.1450^{b}$ & $0.1246^{b}$ & $1959.74^{b}$ & $9.02^{b}$ \\
\hline Se20F & 13.62 & $0.2490^{\mathrm{a}}$ & $0.2290^{\mathrm{a}}$ & $3390.94^{a}$ & $16.18^{\mathrm{a}}$ \\
\hline Hybrid $^{H}$ & ns & $* *$ & ns & $*$ & $*$ \\
\hline N01 & 13.51 & 0.097 & 0.1016 & 1310.11 & 8.18 \\
\hline R10 & 13.50 & 0.129 & 0.1163 & 1741.22 & 11.57 \\
\hline
\end{tabular}

However, soil selenium application also increased selenium content in maize plant tissues, especially during the second year of the study. Besides total selenium accumulation and selenium recovery have increased significantly and almost linearly suggesting a positive response of selenium status in plants to the increase soil selenium fertilization (Table 5). During the first year of the study, such clear pattern was not observed (Table 4). These differences may have been due to differences in climatic and soil conditions from one year to another. Additionally, the results from the second year of the study indicate a strong correlation $(r=0.71)$ between selenium content in whole plant and selenium content in the maize grains (Fig. 1).

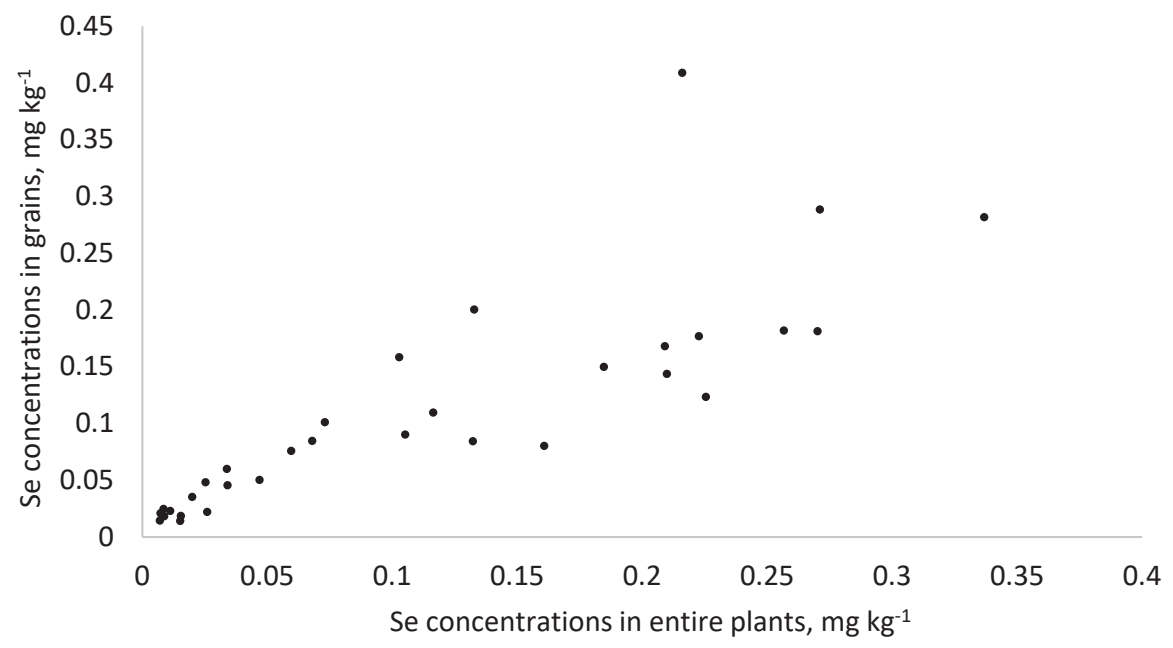

Fig. 1. Correlation between selenium content in entire plants and grains of maize 


\section{Discussion}

Annual differences in total concentration of selenium in maize plants were recorded. Although the soil selenium concentration in 2015 was more than $20 \%$ higher than in 2014, selenium content and total selenium accumulation in plants of control treatments showed the opposite trend. This could be attributed to different amount of rainfall, especially immediately after the sowing of the plants. Heavy rainfall during the phase when root has not yet had time to develop might cause selenium to leach into deeper layers of soil (Stavridou 2011). In 2014, precipitation was much higher than in 2015, especially in spring. As a consequence, there was a low rate of selenium recovery with both soil fertilizing doses (Se10 and Se20) in 2014 since sodium selenate had been added to the soil during the period of intensive precipitation. On the other hand, selenium concentrations in plants tend to decrease as the biomass yield increase (dilution effect) as a result of intensive plant growth (Jarrell and Beverly, 1981). Apart from that, higher biomass yield in the first year could contribute to decreased selenium leaching into deeper layers of the soil. Namely, Wu et al (1996) found that presence of vegetation reduces leaching of minerals because the biomass reduces water drainage through the soil.

Effectiveness of soil selenium application was more evident at a higher rate of applied selenium (Se20), which was more pronounced in 2015. Organic matter content is another soil factor that could influence selenium availability. Generally, plants grown in soils with higher carbon content absorb more selenium from fertilizers, especially at higher doses of selenium (Eich-Greatorex et al. 2007). For these reasons values of selenium plant content, TSeA and RESe in Se20 treatment in 2015 were higher than in 2014 (Tables 4 and 5).

Foliar application of selenium presented superior effect over the soil application of selenium. Yläranta (1983) found soil and foliar selenate application were similarly effective at the low rate $\left(10 \mathrm{~g} \mathrm{ha}^{-1}\right)$ but foliar application was more effective at $50 \mathrm{~g} \mathrm{ha}^{-1}$. This experiment showed superiority of foliar selenium application even at lower selenium doses ( $20 \mathrm{mg} \mathrm{ha}^{-1}$ ). Foliar application of sodium selenate at dosage of $20 \mathrm{~g} \mathrm{ha}^{-1}$ increased selenium content in whole plants 19.5-fold and 23.4-fold during two years. This effect on selenium content in grains (in 2015 only) was less pronounced, showing 11.58-fold increase. However, each $1 \mathrm{~g}$ of foliar-applied selenium increased selenium content in entire plants by $0.016 \mathrm{mg} \mathrm{kg}^{-1} \mathrm{DM}$ and $0.012 \mathrm{mg} \mathrm{kg}^{-1} \mathrm{DM}$ respectively in 2014 and 2015, and by $0.01 \mathrm{mg} \mathrm{kg}^{-1} \mathrm{DM}$ in grains. Other investigations (Curtin et al. 2006, Wang et al. 2013) showed similar effects (superiority of foliar selenium application). On the other hand, Lyons at al. (2004) found that basal selenium fertilization was more effective (better selenium recovery and higher selenium concentrations in the wheat grain) than foliar application. It seems that soil type, climatic conditions and timing of foliar application have influence on effectiveness of selenium foliar fertilizations.

Results of selenium recovery presented in this study (Tables 4 and 5) showed that the foliar application of selenium was more effective, with recovery values of $16.2 \%$ and $26.8 \%$ in 2015 and 2014 respectively. Non-hyperaccumulator plants such as maize accumulate selenium mostly in leaves, so selenium content in leaves is always higher than in seeds (Cappa et al. 2014).

In addition, selenium concentrations between different plant's tissues correlated differently to selenium application methods. Results shown high correlation $(r=0.84)$ between selenium in whole plants and grains under application selenium in soil but no correlation ( $r=-0.07$ ) was observed in case of foliar selenium treatment what could be explained by the fact that the foliar application of selenium was done later in the season, so the plants had less time to transfer selenium into the grains. Additionally, it seems that foliar application of selenium affected Se uptake from soil (Jiang et al. 2015) resulting in the negative coefficient of correlation. Data from this study showed a similar pattern. Regarding the selenium distribution in particular tissues of maize, foliar application as selenium biofortification technique has the same practical use as fertilization of soil with selenium because of entire plants used to ensiling.

Generally, this study confirmed earlier findings that foliar selenium application could be a reliable and effective method to rise selenium content in plants. Conversely, adding selenium to the soil in attempt to increase selenium content in plants is presented with numerous challenges. Soil properties and climatic condition influence the selenium uptake. Selenate is dominant and stable form in well aerated soil with high pH. Contrary to this, in less oxidized soil, selenite is stable Se. Soil bacteria can reduce selenate to selenite. So delaying selenium fertilization until plants have developed enough to be able to efficiently uptake selenium from soil (developed root shortens the time available to reduce selenate and thus could improve selenium recovery (Curtin et al. 2000). So, timing of addition of selenate into the soil may be an important factor in efficacy of selenium biofortification. 
Although the effect of maize variety on selenium content in plants was not consistent, R10 hybrid tended to accumulate more selenium in plants' tissues more efficiently (Tables 4 and 5). Generally, plant genotype could determine the selenium uptake and its accumulation in tissues, and according to this, the plants have been classified as hyperaccumulators, secondary accumulators, and non-accumulators (Galeas et al. 2007). It seems that genetic differences among varieties in the same species are less pronounced. Literature on this subject is still carce, but some research (Farnham et al. 2007) found that selenium accumulation in broccoli depended on which hybrid was used.

Results indicate that foliar selenate application improve selenium status of maize plant enabling it to achive the level that can provide the sufficient amount of selenium in ruminant's nutrition. On the other hand, adding selenium to the soil at the moment of sowing is not the equally effective method as foliar administration. Doses of $20 \mathrm{~g}$ Se ha- ${ }^{-1}$ may achieve the target selenium concentration in whole maize plants depending on biotic and climatic condition.

\section{Conclusions}

Although both selenium application methods reduce the risk of insufficient selenium uptake by plants, selenium foliar spraying showed superior effects. Better selenium accumulation in plants tissues, total selenium accumulation and selenium recovery promote this method as a promising technique in agronomic selenium biofortification strategy. Results of this study suggest that tested hybrids have different abilities to uptake and accumulate selenium in their tissues, which could be very useful in further development of maize hybrids.

\section{Acknowledgement}

This paper is part of research project "Mineral improved food and feed crops for human and animal health" (Balkan-HERD program-Project ID 332160UA) funded by Norwegian Ministry of Foreign Affairs.

\section{References}

Ademi, A., Govasmark, E., Bernhoft, A., Bytyqi, H., Đikić, M., Manojlović, M., Lončarić, Z., Drinić, M., Filipović, A. \& Singh, B.R. 2015. Status of selenium in sheep and dairy cow blood in Western Balkan countries. Acta Agriculturae Scandinavica, Section A Animal Science 65: 1-8.

Antunović, Z., Steiner, Z.D., Vegara, M., Šperanda M., Steiner, Z.V. \& Novoselec, J. 2010. Concentration of selenium in soil, pasture, blood and wool of sheep. Acta Veterinaria Belgrade 60: 263-271. https://doi.org/10.2298/AVB1003263A

Aspila, P. 2005. History of selenium supplemented fertilization in Finland. In: Twenty years of selenium fertilization. 8-9 September 2005, Helsinki, Finland. p. 8-13.

Broadley, M.R., White, P.J., Bryson, R.J., Meacham, M.C., Bowen, H.C., Johnson, S.E., Hawkesford, M.J., McGrath, S.P., Zhao, F.J., Breward, N., Harriman, M. \&Tucker, M. 2006. Biofortification of UK food crops with selenium. Proceedings of the Nutrition Society, 65: 169-181. https://doi.org/10.1079/PNS2006490

Cappa, J.J., Cappa, P.J., El Mehdawi, A.F., McAleer, J.M., Simmons, M.P. \& Pilon-Smits, E.A. 2014. Characterization of selenium and sulfur accumulation across the genus Stanleya (Brassicaceae): a field survey and common-garden experiment. American Journal of Botany 101: 830-839. https://doi.org/10.3732/ajb.1400041

Curtin, D., Hanson, R., Lindley, T.N. \& Butler, R.C. 2006. Selenium concentration in wheat (Triticum aestivum) grain as influenced by method, rate, and timing of sodium selenate application. New Zealand Journal of Crop and Horticultural Science 34: 329-339. https://doi.org/10.1080/01140671.2006.9514423

Džomba, E., Đikić, M., Lončarić, Z., Gadžo, D., Ivezić, V., Muratović, S., Šperanda, M. \& Singh, B.R. 2014. Selenium status of cows and sheep as a consequence of regional differences and feeding practice on small farms in central Bosnia and eastern Slavonia. Krmiva 56: 63-70. (in Croatian).

Ebrahimi, N., Hartikainen, H., Simojoki, A., Hajiboland, R. \& Seppänen, M.M. 2015. Dynamics of dry matter and selenium accumulation in oilseed rape (Brassica napus L.) in response to organic and inorganic selenium treatments. Agricultural and Food Science 24: 104-117. https://doi.org/10.23986/afsci.48346

Eich-Greatorex, S., Sogn, T.A., Øgaard, A.F. \& Aasen, I. 2007. Plant availability of inorganic and organic selenium fertilizer as influenced by soil organic matter content and pH. Nutrient Cycling in Agroecosystems 79: 221-231. https://doi.org/10.1007/s10705007-9109-3

Egnér, H., Riehm, H. \& Domingo, W.R. 1960. Untersuchungen uber die chemische Bodenanalyse als Grundlage fur die Beurteilung des Nährstoffzustandes der Böden. II. Chemische Extraktionsmethoden zur Phosphor- und Kaliumbestimmung. Kungliga Lantbrukshögskolans Annaler 26: 199-215. (in German).

Farnham, M.W., Hale, A.J., Grusak, M.A. \& Finley, J.W. 2007. Genotypic and environmental effects on selenium concentration of broccoli heads grown without supplemental selenium fertilizer. Plant Breeding 126: 195-200. https://doi.org/10.1111/j.14390523.2007.01294.x 
Galeas, M.L., Zhang, L.H., Freeman, J.L., Wegner, M. \& Pilon-Smits E.A.H. 2007. Seasonal fluctuations of selenium and sulfur accumulation in selenium hyperaccumulators and related non-accumulators. New Phytologist 173:517-525. https://doi.org/10.1111/ j.1469-8137.2006.01943.x

Gissel-Nielsen, G. 1993. General aspects of selenium fertilization. In: Arne Froslie (ed.). Problems on Selenium in Animal Nutrition. Norwegian Journal of Agricultural Sciences supplement 11: 135-140.

ISO 1994. Soil quality - Determination of pH. https://www.iso.org/standard/18454.html

ISO 1995. Soil quality - Extraction of trace elements soluble in aqua regia. https://www.iso.org/standard/19418.html

Jarrell, W.M. \& Beverly, R.B. 1981. The dilution effect in plant nutrition studies. Advances in Agronomy 34:197-224. https://doi. org/10.1016/S0065-2113(08)60887-1

Jiang, Y., Zeng, Z.H., Bu, Y., Ren, C.Z., Li, J.Z., Han, J.J., Tao, C., Zhang, K., Wang, X.X., Lu, G.X., Li, X.Y. \& Hu, Y.G. 2015. Effects of selenium fertilizer on grain yield, Se uptake and distribution in common buckwheat (Fagopyrum esculentum Moench). Plant Soil and Environment 61: 71-377.

Kingstone, H.M. \& Lassie, L.B. 1986. Microwave energy for acid decomposition at elevated temperatures and pressures using biological and botanical samples. Analytical Chemistry 58:2534-41. https://doi.org/10.1021/ac00125a038

Li, H.F., McGrath, S.P. \& Zhao, F.J. 2008. Selenium uptake, translocation and speciation in wheat supplied with selenate or selenite. New Phytologist 178 :92-102. https://doi.org/10.1111/j.1469-8137.2007.02343.x

Lyons, G., Ortiz-Monasterio, I., Stangoulis, J. \& Graham, R. 2005. Selenium concentration in wheat grain: Is there sufficient genotypic variation to use in breeding? Plant and Soil, 269: 369-380. https://doi.org/10.1007/s11104-004-0909-9

Lyons, G.H., Lewis, J., Lorimer, M.F., Holloway, R.E., Brace, D.M., Stangoulis, J.C.R. \& Graham, R.D. 2004. High-selenium wheat: agronomic biofortification strategies to improve human nutrition food. Agriculture and Environment 2: 171-178.

Lyons, G.H., Stangoulis, J. \& Graham, R. 2003. High-selenium wheat: biofortification for better health. Nutrition Research Reviews 16: 45-60. https://doi.org/10.1079/NRR200255

Mangan, B.N., lashari, M.S., Hui, L., Ali, M., Baloch, A.W. \& Song, W. 2016. Comparative analysis of the selenium concentration in grains of wheat and barley species. Pakistan Journal of Botany 48: 2289-2296.

Marijanušić, K., Manojlović, M., Bogdanović, D., Čabilovski, R. \& Lombnaes, P. 2017. Mineral composition of forage crops in respect to dairy cow nutrition. Bulgarian Journal of Agricultural Science 23: 204-212.

Mineev, V.G., Sicev, V.G. \& Ameljackin, O.A. 2001. Praktikum po Agrohimi. University of Moscow, Russian Academy of Agricultural Sciences. p. 215-217.

Missana, T., Alonso, U. \& García-Gutiérrez, M. 2009. Experimental study and modeling of selenite sorption onto illite and smectite clays. Journal of Colloid and Interface Science 334, 132-138. doi: 10.1016/j.jcis.2009.02.059. https://doi.org/10.1016/j. jcis.2009.02.059

NRC 2001. Nutrient Requirements of Dairy Cattle. 7th rev. ed. Washington, D.C.: The National Academies Press. 408 p.

Pehrson, B. 1993. Diseases and diffuse disorders related to selenium deficiencies in ruminants. Norwegian Journal of Agricultural Sciences 11: 79-93.

Ramirez-Cabral, N.J.Z., Kumar, L. \& Shabani, F. 2017. Global alterations in areas of suitability for maize production from climate change and using a mechanistic species distribution model (CLIMEX). Scientific reports 7: 5910. https://doi.org/10.1038/s41598017-05804-0

Ros, G.H., van Rotterdam, A.M.D., Bussink, D.W. \& Bindraban, P.S. 2016. Selenium fertilization strategies for bio-fortification of food: an agro-ecosystem approach. Plant and Soil 404: 99-112. https://doi.org/10.1007/s11104-016-2830-4

Sakizadeh, M., Sharafabadi, F.M.S., Shayegan, E. \& Ghorbani, H. 2016. Concentrations and Soil-To-Plant Transfer Factor of Selenium in Soil and Plant Species from an Arid Area. IOP Conference Series: Earth and Environmental Science 44: 052027. https:// doi.org/10.1088/1755-1315/44/5/052027

Seppälä, A., Madrid Albarran, J., Miettinen, H., Palomo Siguero, M., Juutinen, E. \& Rinne, M. 2014. Selenium supplementation by addition of sodium selenate with silage additive. Agricultural and Food Science 23: 81-88. https://doi.org/10.23986/afsci.41179

Seppänen, M.M., Kontturi, J., Heras, I.L., Madrid, Y., Camara, C. \& Hartikainen, H. 2010. Agronomic biofortification of Brassica with selenium - enrichment of SeMet and its identification in Brassica seeds and meal. Plant and Soil 337: 273-283. https://doi. org/10.1007/s11104-010-0523-y

Stadlober, M., Sager, M. \& Irgolic, K. J. 2001. Effects of selenate supplemented fertilization on the selenium level of cereals-identification and quantification of selenium compounds by HPLC-ICP-MS. Food Chemistry 73: 357-366. https://doi.org/10.1016/ S0308-8146(01)00115-7

Stavridou, E. 2011. The effects of cropping systems on selenium and glucosinolate concentrations in vegetables. Ph.D.-dissertation, Faculty of Science and Technology, Aarhus University. 33 p.

Surai, P.F., Fisinin, V.I. \& Papazyan, T.T. 2008. Selenium deficiency in Europe: Cause and consequences. In: Surai, P.F., Taylor, Pickard, J.A. (eds.). Current advances in selenium research and applications. Wageningen Academic Publisher. p. 13-44. https://doi. org/10.3920/978-90-8686-642-7

Suttle, N. 2010. Mineral Nutrition of Livestock. 4th Ed. Commonwealth Agricultural Bureaux International, Oxfordshire, UK. p. 377-425. https://doi.org/10.1079/9781845934729.0377

Tapiero, H., Townsend, D.M. \& Tew, K.D. 2003. The antioxidant role of selenium and seleno-compounds. Biomedicine \& Pharmacotherapy 57: 134-144. https://doi.org/10.1016/S0753-3322(03)00035-0

Terry, N., Zayed, A.M., de Souza, M.P. \& Tarun, A.S. 2000. Selenium in higher plants. Annual Review of Plant Physiology and Plant Molecular Biology 51: 401-432. https://doi.org/10.1146/annurev.arplant.51.1.401 
Underwood, E.J. \& Suttle N.F. 1999. The mineral nutrition of livestock. 3.ed. New York: CABI Publishing, p. 446. https://doi. org/10.1079/9780851991283.0000

Wang, J., Wang, Z., Maoa, H., Zhaoa, H. \& Huanga, D. 2013. Increasing Se concentration in maize grain with soil- or foliar-applied selenite on the Loess Plateau in China. Field Crops Research 150: 83-90. https://doi.org/10.1016/j.fcr.2013.06.010

White, P.J. 2016. A review: Selenium accumulation by plants. Annals of Botany 117: 217-235. https://doi.org/10.1093/aob/mcv180

Winkel, L.H., Vriens, B., Jones, G.D., Schneider, L.S., Pilon-Smits, E. \& Bañuelos, G.S. 2015. Selenium cycling across soil-plant-atmosphere interfaces: a critical review. Nutrients 7: 4199-4239. https://doi.org/10.3390/nu7064199

Witchel, J.J. 1998. A review of selenium deficiency in grazing ruminants. Part 2. Towards a more rational approach to diagnosis and prevention. New Zealand Veterinary Journal 46: 54-58. https://doi.org/10.1080/00480169.1998.36056

Wu, L., Mantgem, P.J. \& Guo, X. 1996. Effects of forage plant and field legume species on soil selenium redistribution, leaching, and bioextraction in soils contaminated by agricultural drain water sediment. Archives of Environmental Contamination and Toxicology 31: 329-338. https://doi.org/10.1007/BF00212671

Yläranta, T. 1993. Selenium fertilization in Finland: selenium soil interactions. In: Problems on selenium in animal nutrition. NJF Symposium, As, Norway. p. 141-149.

Yli-Halla, M. 2005. Influence of Se fertilization on soil Se status. In: Twenty years of selenium fertilization. 8-9 September 2005, Helsinki, Finland. p. 25-32. 